\title{
Pengaruh Resiliensi terhadap Orientasi Karir Siswa Kelas XII SMA Se-Kecamatan Candisari Semarang
}

\author{
Lutfi Sultana Dwi Adiyanto', Eko Nusantoro² \\ 1,2 Universitas Negeri Semarang
}

*Corresponding author, e-mail: lutfisultana7@gmail.com

\begin{abstract}
Abstrak. Banyak siswa setelah lulus dari pendidikan SMA mengalami kesulitan untuk memilih jurusan di perguruan tinggi yang sesuai minat, kemampuan intelektual serta harapan karir setelah lulus dari perguruan tinggi tersebut. Penelitian ini bertujuan untuk mengidentifikasi adakah pengaruh resiliensi terhadap orientasi karir siswa kelas XII SMA . Penelitian ini menggunakan desain penelitian ex post facto. Alat pengumpul data menggunakan skala psikologi resiliensi dengan tingkat signifikansi antara 0,000-0,071, sedangkan koefisien reliabilitas alpha sebesar 0,929, dan skala orientasi karir dengan tingkat signifikansi antara 0,000-0,045 dengan koefisien reliabilitas alpha sebesar 0,895. Sampel yang terlibat 146 siswa dari populasi 186 siswa dengan teknik pengambilan sampel proportionate random sampling. Adapun teknik analisis data menggunakan analisis korelasi product moment pearson. Hasil analisis deskriptif kuantitatif menunjukkan bahwa tingkat resiliensi siswa kelas XII SMA se-Kecamatan Candisari Semarang berada pada kategori tinggi yaitu 54,22\% dari total sampel keseluruhan, sedangkan tingkat orientasi karir siswa kelas XII SMA se-Kecamatan Candisari Semarang berada pada ketori sedang yaitu 77, $23 \%$ dari total keseluruhan sampel. Selanjutnya hasil analisis korelasi product moment pearson didapatkan hasil pengaruh resiliensi terhadap orientasi karir siswa SMA sebesar 58,8\% (r= 0,588 ) dimana sisnya dipengaruhi oleh faktor lain yang tidak diteliti dalam penelitian ini. Berdasarkan hasil tersebut, maka guru BK diharapkan dapat mempertahankan tingkat resiliensi siswa serta meningkatkan pengetahuan orientasi karir siswa sehingga siswa mampu dalam mengambil setiap keputusan karir kedepannya. dan orientasi karir.
\end{abstract}

Kata kunci: Orientasi Karir , Resiliensi.

\section{Pendahuluan}

Penyelenggaraan pendidikan di SMA diharapkan dapat membangun pribadi yang mampu bersaing dan menjembatani individu dalam meraih kesuksesan baik dalam dunia pendidikan maupun dunia kerja. Pendidikan menengah bertujuan untuk melanjutkan dan meluaskan pendidikan dasar serta menyiapkan peserta didik menjadi anggota masyarakat yang memiliki kemampuan mengadakan hubungan timbal balik dengan lingkungan sosial, budaya dan alam sekitar, serta dapat mengembangkan kemampuan lebih lanjut dalam dunia kerja atau pendidikan tinggi (Sisdiknas, 2003). Kurikulum SMA dirancang untuk mempersiapkan para siswa melanjutkan pendidikan ke jenjang berikutnya, yakni memasuki perguruan tinggi di sisi lain (ABKIN, 2013). Setelah siswa melewati tahap kelulusan pendidikan di tingkat SMA, selayaknya ia melanjutkan pendidikan ke jenjang perguruan tinggi.

Bimbingan dan konseling bertujuan untuk mencapai tujuan pendidikan nasional melalui layanan yang diberikan kepada siswa dalam membantu menuntaskan tugas-tugas perkembangannya, salah satu diantaranya adalah tugas perkembangan karir. Penyelenggaraan pendidikan di SMA memang tidak secara khusus diarahkan untuk menghasilkan lulusan yang siap kerja, akan tetapi lulusan SMA diharapkan dapat membangun pribadi yang mampu bersaing dan 
menjembatani individu dalam meraih kesuksesan baik dalam dunia pendidikan maupun dunia kerja (Sisdiknas, 2003). Siswa SMA berada pada masa remaja madya yang berusia antara 15-18 tahun dan telah memiliki minat terhadap pekerjaan. Hal tersebut juga diwujudkan dalam proses pembentukan orientasi, minat, dan rencana masa depan individu (Desmita, 2009). Jika dilihat dari teori perkembangan karir menurut Super, maka siswa SMA berada pada tahap eksplorasi, dimana pada tahap ini individu telah memikirkan berbagai alternative pilihan karir, tetapi belum mengambil keputusan yang mengikat (Winkel \& Hastuti, 2006).

Penentuan pilihan karir didasarkan pada keputusan siswa itu sendiri berdasarkan pada pemahaman mengenai kemampuan dan minat serta pengenalan karir yang ada di masyarakat. Kesulitan yang dialami siswa dalam memilih dan menentukan karir tidaklah dapat dipungkiri, banyak siswa yang kurang memahami bahwa karir merupakan jalan hidup dalam usaha menggapai kehidupan yang baik di masa mendatang. Setelah siswa melewati tahap kelulusan pendidikan di tingkat SMA, selayaknya ia melanjutkan pendidikan ke jenjang perguruan tinggi. Akan tetapi, sistem pendidikan di perguruan tinggi berbeda dengan pendidikan di SMA, salah satu perbedaan utama adalah perguruan tinggi memiliki banyaknya pilihan fakultas dan jurusan. Hal tersebut mengakibatkan banyak siswa mengalami kesulitan untuk memilih jurusan di perguruan tinggi yang sesuai minat, kemampuan intelektual serta harapan karir setelah lulus dari perguruan tinggi tersebut. Dalam situasi ini terdapat permasalahan yang menarik untuk diteliti, yakni mengenai pengaruh ketahanan siswa (resiliensi) dalam pengambilan keputusan ketika seorang siswa lulusan SMA hendak memilih jurusan serta perguruan tinggi yang dia inginkan.

Hal tersebut sesuai dengan fenomena yang dialami siswa SMA di Kecamatan Candisari Semarang yakni mereka dihadapkan pada tingginya persaingan masuk perguruan tinggi favorit dan adanya keraguan dalam pengambilan keputusan ketika orang tuanya ikut menentukan pilihan yang tidak sesuai dengan cita-citanya. Kemudian berdasarkan observasi dan wawancara pada tanggal 4 November 2019, siswa kelas XII SMA Sint Louis ditemukan fakta bahwa siswa sering bingung dalam pengambilan keputusan jurusan studi lanjut bahkan terdapat siswa yang mengaku memilih jurusan hanya asal-asalan. Selain itu, fakta bahwa peserta didik SMA belum mampu mengambil keputusan terkait memilih perguruan tinggi juga dibahas dalam penelitian yang dilakukan oleh Hayadin (2018) dan diperoleh hasil bahwa sebanyak 47,7\% peserta didik setingkat SMA (MA dan SMK) sudah mempunyai pilihan perguruan tinggi dan 52,3\% belum mempunyai pilihan perguruan tinggi. Hasil penelitian ini selaras dengan fakta yang peneliti temui di lapangan yang menunjukan bahwa pada peserta didik setingkat SMA masih banyak yang kesulitan mengambil keputusan yang tepat terkait studi lanjut ke perguruan tinggi. Hal ini menunjukkan kurangnya pemahaman orientasi karir siswa. Orientasi masa depan berkaitan erat dengan harapan, tujuan, standar, rencana dan strategi pencapaian tujuan di masa mendatang (Doni, 2019).

Menurut Supriyatna dalam Saputri, Purwati \& Yusuf (2018), beberapa permasalahan yang sering muncul pada remaja yang berhubungan dengan orientasi karir diantaranya: (1) siswa dihadapkan oleh beban yang berat mengenai harapan-harapan orang lain disekitarnya untuk sukses setelah lulus (2) bidang atau jurusan yang diambil bukan dikarenakan pilihannya sendiri (3) belum mengetahui jenis pekerjaan yang cocok dengan kemampuannya (4) masih bingung memilih pekerjaan yang sesuai dengan minat dan kemampuannya (5) pesimis mendapatkan pekerjaan yang diharapakan. Berdasarkan perspektif teori Super permasalahan-permasalahan yang muncul berakar 
dari tahap perkembangan karir yang dialami oleh siswa, oleh sebab itu perlu adanya peningkatan pengetahuan siswa mengenai orientasi karir sehingga terhindar dari masalah-masalah yang dapat menghambat perkembangan karir pada siswa.

Seseorang dengan orientasi karir yang baik maka akan mengantarkan sesorang menjadi individu yang mempunyai daya saing. Sebaliknya, rendahnya orientasi karir dapat menyebabkan kesalahan dalam mengambil keputusan karir secara tepat serta kesalahan dalam menentukan fase kehidupan lanjutan. Individu yang tidak mempunyai orientasi karir akan mengalami kesulitan dalam merencanakan masa depan yang berdampak pada keberlangsungan dan kebahagiaan hidup dimasa depan (Kamil \& Daniati, 2016).

Orientasi karir dapat dipengaruhi oleh resiliensi, hal tersebut sesuai dengan penelitian yang dilakukan oleh Hasanah dan Rusmawati (2018) yang menyebutkan bahwa resiliensi memiliki pengaruh terhadap kematangan karir remaja. Fuster (2014) yang mengungkapkan bahwa individu yang memiliki resiliensi menganggap kesulitan sebagai tantangan, bukan sebagai ancaman. Tantangan dalam hal ini adalah sikap individu terhadap pemilihan pendidikan lanjutan dan pekerjaan yang ditunjukkan adanya tujuan yang jelas, pemahaman diri, pertimbangan atas peluang. Hal tersebut sesuai dengan penelitian yang dilakukan oleh Suwarjo (2008) bahwa individu dengan tingkat resiliensi rendah tidak dapat menilai, mengatasi, dan meningkatkan diri ataupun mengubah dirinya dari keterpurukan atau kesengsaraan dalam hidup sehingga dalam pengambilan keputusan dalam karir tidak akan maksimal.

Resiliensi memiliki peran yang penting dalam bidang akademik. Resiliensi merupakan kemampuan individu untuk dapat bertahan dan mengatasi berbagai kesulitan-kesulitan yang dialaminya Wish (dalam Pelling, 2011). MacDermid, dkk (2008) mengungkapkan bahwa resiliensi adalah interaksi antara individu dengan berbagai macam masalah, stressor, kesulitan ataupun tarauma yang berlangsung sepanjang hidup. Masten (2001) mengeksplorasi model motivasi serta memperkenalkan model resiliensi akademik. Motivasi merupakan hal yang sangat penting bagi keberhasilan akademik, akan tetapi hal tersebut dapat hilang apabila siswa tidak tahan terhadap tantangan, tekanan belajar, dan tekanan yang ada di sekolah. Resiliensi pada remajaOleh karena itu penting sekali siswa memiliki motivasi dan ketahanan terhadap tekanan akademis. Siswa yang tidak memiliki resiliensi akademik dapat beresiko ada pada kemunduran, stres, atau tekanan di sekolah..

Tujuan dari penelitian ini adalah untuk memperoleh gambaran mengenai pengaruh resiliensi terhadap orientasi karir siswa kelas XII SMA, serta dengan hasil tersebut mampu memberikan implikasi pada penerapan layanan konseling karir pada siswa SMA se-Kecamatan Candisari Semarang..

\section{Metode}

Jenis penelitian ini termasuk dalam penelitian yang dilakukan tanpa melakukan eksperimen artinya perlakuan atau variabel bebas terjadi secara alami tanpa di manipulasi (expost facto). Jenis penelitian yang akan digunakan adalah penelitian kuantitatif deskriptif korelasional. Terdapat dua variabel dalam penelitian ini yaitu resiliensi $(\mathrm{X})$ dan orientasi karir $(\mathrm{Y})$. Teknik yang digunakan oleh peneliti menggunakan teknik pengambilan sampel berupa proportionate random sampling dengan 
jumlah sampel 146 siswa dari 186 siswa dengan taraf kesalahan 5\% yang berasal dari siswa kelas VII SMA se-Kecamatan Candisari Semarang.

Alat pengumpulan data yang digunakan dalam penelitian ini disusun berdasarkan skala likert. Data Orientasi karir diambil menggunakan skala orientasi karir dengan jumlah 29 item pernyataan dengan hasil uji validitas mengkorelasikan skor item dengan skor total. Hasil uji validitas menunjukkan bahwa tingkat signifikansi berkisar antara 0,000-0,045, dengan koefisien reliabilitas alpha sebesar 0,895. Data skala orientasi karir terdiri dari lima aspek, yaitu: informasi mengenai pekerjaan, informasi mengenai orang lain dalam dunia kerja bakat, minat, karakter kepribadian.

Alat pengumpulan data resiliensi diungkap menggunakan skala resiliensi dengan jumlah 24 item pernyataan dengan hasil uji validitas mengkorelasikan skor item dengan skor total. Hasil uji validitas menunjukkan bahwa tingkat signifikansi berkisar antara 0,000-0,071 sedangkan koefisien reliabilitas alpha sebesar 0,929. Data skala resiliensi terdiri dari sembilan aspek, yaitu determinasi, endurance, adaptability, kebahagiaan, ketekunan, kesehatan, prestasi, harapan dan relaksi.

Teknik analisis data yang digunakan dalam penelitian ini adalah analisis deskriptif yang bertujuan untuk memberikan gambaran umum dan analisis korelasi product moment pearson untuk mencari pengaruh resiliensi terhadap orientasi karir siswa SMA. Proses analisis data dilakukan dengan menggunakan bantuan SPSS 21..

\section{Hasil dan Diskusi}

Berdasarkan tabel 1. hasil analisis deskriptif mengenai gambaran mengenai tingkat resiliensi siswa Kelas XII SMA se-Kecamatan Candisari sejumlah 146 responden menunjukan bahwa tingkat resiliensi siswa Kelas XII SMA Se-Kecamatan Candisari sebagian besar memiliki tingkat resiliensi tinggi dengan total 77 siswa atau 54,22\% dari total sampel keseluruhan. Sehingga dapat dikatakan bahwa tingkat resiliensi siswa Kelas XII SMA Se-Kecamatan Candisari berada pada kategori tinggi.

Tabel 1. Hasil Analisis Deskriptif Resiliensi

\begin{tabular}{ccc}
\hline Kategori & Jumlah & Prosentase \\
\hline Tinggi $>82$ & 77 & $54,22 \%$ \\
Sedang 66-82 & 60 & $42,25 \%$ \\
Rendah $<66$ & 5 & $3,52 \%$ \\
\hline
\end{tabular}

Berdasarkan tabel 2. orientasi karir siswa Kelas XII SMA Se-Kecamatan candisari sebagian besar memiliki tingkat orientasi karir sedang dengan total 103 siswa atau 77, 23\% dari total keseluruhan sampel. Sehingga dapat dikatakan bahwa tingkat orientasi karir siswa Kelas XII SMA se-Kecamatan Candisari berada pada kategori sedang.

Tabel 2. Hasil Analisis Deskriptif Orientasi Karir

\begin{tabular}{ccc}
\hline Kategori & Jumlah & Prosentase \\
\hline Tinggi $>91$ & 22 & $15,49 \%$ \\
Sedang $77-91$ & 103 & $72,53 \%$ \\
Rendah $<77$ & 17 & $11,97 \%$ \\
\hline
\end{tabular}


Dari hasil tabel 3. mengenai resiliensi teradap orientasi karir 146 responden, didapatkan hasil signifikansi sebesar $(p=0.000)$ serta nilai korelasi product moment sebesar $(r=0.588)$. Artinya dengan nilai signifikansi $(\mathrm{p}=0.000<0.05)$ maka H0 ditolak, dan Ha diterima, sehingga dapat dinyatakan bahwa ada pengaruh yang positif dan signifikan antara resiliensi terhadap orientasi karir selain itu, diperoleh nilai korelasi sebesar $(\mathrm{r}=0.588)$, maka variabel resiliensi dengan orientasi karir memiliki derajat hubungan yang sedang dikarenakan nilai $(\mathrm{r}=0.588)$ berada pada rentang 0.50 0.699 derajat interpretasi koefisien korelasi. Sehingga dapat dikatakan bahwa resiliensi mempengaruhi orientasi seseorang sebesar 58,8\% dimana sisanya tidak dibahas dalam penelitian ini.

Tabel 3. Hasil Analisis Korelasi Product Moment Pearson

\begin{tabular}{ccccc}
\hline Variabel & Jumlah Responden & r x & r y & Sig. (2-tailed) $\boldsymbol{P}$ \\
\hline Resiliensi & 146 & 1 & 0.588 & 0.000 \\
Orientasi Karir & 146 & 0.588 & 1 & 0.000 \\
\hline
\end{tabular}

Penelitian ini dimaksudkan untuk menguji pengaruh resiliensi terhadap orientasi karir. Temuan penelitian ini membuktikan bahwa resiliensi memiliki pengaruh terhadap orientasi karir. Dalam penelitian ini menunjukkan hasil analisis data bahwa terdapat pengaruh antara resiliensi terhadap orientasi karir siswa SMA kelas XII se-Kecamatan Candisari Semarang. Hasil tersebut menjawab hipotesis yang diajukan. Hasil pengujian hubungan antara variabel resiliesi teradap orietasi karir menggunakan uji korelasi product moment pearson.

Hasil penelitian menunjukkan bahwa siswa Kelas XII SMA Se-Kecamatan Candisari memiliki resiliensi dengan katagori tinggi sedangkan memiliki orientasi karir dengan katagori sedang. Resiliensi mempengaruhi orientasi karir siswa sebesar 58.8\%(r=0.588) dimana sisanya tidak dibahas dalam penelitian ini. Dalam resiliensi teerdapat beberapa faktor utama yang mempengaruhi orientasi karir siswa, diantaranya determinasi, endurance, adaptability, kebahagiaan, ketekunan, kesehatan, prestasi, harapan dan relaksi.

Resiliensi dan Orientasi Karir dalam ranah bimbingan dan konseling berkaitan dengan bidang pribadi dan karir. Resiliensi berkaitan dengan kemampuan individu untuk bertahan dan bangkit dari tekanan ataupun stressor yang dimiliki. Sedangkan Orientasi karir berkaitan dengan sebuah pendirian umum tentang kematangan karir siswa yang diharapkan akan memberikan sebuah ringkasan atau kumpulan dari apa yang diharapkan siswa dengan istilah orientasi menuju karir. Hal tersebut sesuai dengan penelitian yang dilakukan oleh Hasanah dan Rusmawati (2018) yang menyebutkan bahwa resiliensi memiliki pengaruh terhadap kematangan karir remaja. Sehingga dapat diartikan bahwa semakin tinggi resiliensi seseorang maka semakin tinggi pula orientasi karir yang dimilikinya dan sebaliknya seseorang dengan resiliensi yang rendah maka orientasi karir yang dimilikinya juga rendah.

Orientasi karir adalah pemahaman seseorang terhadap gambaran pribadi yang mendorong untuk melakukan pemilihan karir dan percaya bahwa orientasi karir sangat dipengaruhi dan diperkuat oleh faktor-faktor internal seseorang. Sehingga dapat disimpulkan bahwa orientasi karir merupakan pemahaman terhadap pekerjaan atau karir yang akan dimiliki oleh individu dengan tujuan yang berbeda sesuai bakat dan minat yang dimiliki. Menurut Slameto, Seligman, dan Holland dalam Margareth (2006), faktor-faktor yang mempengaruhi siswa dalam orientasi karir dibagi 
menjadi dua kelompok. Pertama, faktor dari dalam diri siswa yang meliputi minat, kepribadian, dan citra/konsep diri. Sedangkan faktor dari luar diri remaja meliputi orangtua, teman sebaya, lingkungan sosial ekonomi budaya, dan saran tes bakat minat.

Adanya pengaruh positif dan signifikan yang telah diuraikan menjawab rumusan masalah penelitian ini. Dari hasil penelitian, rumusan masalah dapat terjawab bahwa terdapat pengaruh positif dan signifikan resiliensi terhadap orientasi siswa SMA se-Kecamatan Candisari Semarang. Pentingnya pengembangan resiliensi pada siswa dapat dilakukan dengan adanya pemberian layanan bimbingan dan konseling baik dalam bentuk klasikal, kelompok, maupun individu. Dengan adanya layanan bimbingan dan konseling dapat membantu siswa dalam meningkatkan Resiliensi serta memperkuat dan memperjelas orientasi karir siswa.

\section{Kesimpulan}

Berdasarkan hasil penelitian dan pembahasan yang diuraikan, maka kesimpulan dalam penelitian ini yaitu tingkat resiliensi siswa berada pada kategori tinggi sedangkan tingkat orientasi siswa berada pada kategori sedang serta terdapat hubungan positif dan signifikan resiliensi dalam mempengaruhi orientasi karir siswa kelas VII SMA se-Kecamatan Candisari Semarang sebesar 58,8 $\%$ sehingga diharapkan guru BK dapat mempertahankan tingkat resiliensi siswa yang telah berada pada kategori tinggi serta meningkatkan pengetahuan orientasi karir siswa yang masih dalam kategori sedang sehingga siswa mampu dalam mengambil setiap keputusan karir kedepannya.

Keterbatasan dalam penelitian ini yaitu penelitian hanya dilakukan di tiga sekolah, terdapat beberapa guru bimbingan dan konseling yang belum mengerti tentang resiliensi sehingga peneliti kurang mendapatkan masukan dari guru BK selama melakukan penelitian

\section{Referensi}

ABKIN. 2013. Panduan Umum Pelayanan Bimbingan dan Konseling: Pelayanan Arah Peminatan Peserta Didik. Jakarta : Direktorat Jenderal Peningkatan Mutu Pendidikan dan Tenaga Kependidikan Departemen Pendidikan Nasional.

Alfaiz, A., Hidayat, H., Yandri, H., Sari, A. T. L., Sendayu, F. S., Suarja, S., \& Arjoni, A. (2021). Identification of Perceived Self-Efficacy to Predict Student's Awareness in Career Readiness. Islamic Guidance and Counseling Journal, 4(1), 124-132.

Alfaiz, A., Yandri, H., Yuzarion, Y., Lestari, L. P. S., \& Heriyani, E. (2019). Persepsi agentik individu untuk mencapai prestasi pribadi dalam aktivitas karir: riset pendahuluan. Psychocentrum Review, 1(2), 85-95.

Desmita. 2009. Psikologi Perkembangan. Bandung: PT Remaja Rosdakarya.

Doni, Sri Roman. 2019. Pengaruh Orientasi Masa Depan dan Dukungan Orangtua terhadap Pengambilan Keputusan dalam Memilih Program Studi/ Kuliah Siswa Kelas XI SMA N 16 Samarinda. Psikoborneo. 7, 570-578.

Fuster, Valentin. 2014. The Power of Resilience. Journal of the American Collage of Cardiology. 64, 840842. 
Hasanah, Nasiyatul., Rusmawati, Diana. 2018. Hubungan antara Resiliensi dengan Kematangan Karir pada Remaja Penyandang Disabilitas Daksa Prof. Dr. Soeharso Surakarta. Jurnal Empati. 7, 286-290.

Hayadin. 2018. Pengambilan Keputusan Profesi pada Siswa. Jurnal Teknodika. 8, 59-65.

Kamil, B., \& Daniati. 2016. Layanan informasi karir dalam meningkatkan kematangan karir pada peserta didik kelas X di sekolah Madrasah Aliyah Qudsiyah Kotabumi Lampung Utara. Jurnal bimbingan dan konseling. 3, 472-480.

MacDermid., Shelly., M., Samper., Rita., Schwarz, R., Nishida, J., \& Nyaronga, D. 2008. Understanding and promoting resilience in military families. West Lafayetter: Military Family Researc Institue at Purdue University.

Masten. 2001. Ordinary Magic: Resilience Processes in Development. America Psychologist. 56, 227238.

Pelling, M. 2011. Adaptation to climate change from resilience to transformation. London and New York. Routledge.

Saputri, Yessiana Yolanda., Purwanti., Yusuf, Abas 2018. Orientasi Karir Pada Peserta Didik di SMA Negeri 1 Sungai Raya. Jurnal Pendidikan dan Pembelajaran Khatulistiwa. 7, 162-169.

Sisdiknas. 2003. Undang-undang Sisdiknas. Dalam bentuk e-book dinduh di www.unpad.ac.id (diakses 28-03-2020)

Suwarjo. 2008. Konseling Teman Sebaya untuk Peningkatan Resiliensi Remaja dalam Layanan Bimbingan dan Konseling di SLTP dan SLTA. Jurnal Kajian Bimbingan dan Konseling. 4, 196202.

Winkel, W.S. dan Hastuti, Sri. 2006. Bimbingan dan Konseling di Institusi Pendidikan. Jakarta: PT. Gramedia Widiasarana Indonesia.

Yandri, H., Juliawati, D., Alfaiz, A., Ramdani, R., Rusliah, N., Yuzarion, Y., ... \& Syaputra, Y. D. (2021). The Implementation of STIFIn Intelligence Test for Students' Career Planning: An Introduction and Impact of STIFIn Approach. Psychol Psychother Res Stud, 4(5). 